\title{
Interaction between autophagy, apoptosis and necrosis of infant mice (Mus musculus) brain cells from its carbofuran exposed mothers during lactation periods
}

\author{
Epy Muhammad Luqman ${ }^{1,2}$, Widjiati², Eka Pramyrtha Hestianah², \\ Benyamin Christoffel Tehupuring ${ }^{2}$, Lita Rakhma Yustinasari ${ }^{2}$ \\ Universitas Airlangga, ${ }^{1}$ Post Graduate School, ${ }^{2}$ Faculty of Veterinary Medicine, \\ Department of Veterinary Anatomy, Surabaya, Indonesia
}

Received July 9, 2019

Accepted May 26, 2020

\begin{abstract}
This study aimed to determine the mechanism of autophagy, apoptosis and necrosis in the neurons of infant mice (Mus musculus) whose mothers were exposed to carbofuran during the lactation period. This experimental study included 20 mice; carbofuran was administered at $\mathrm{LD}_{50}$ fractions by gavage to mice at the doses of $1.25 \mathrm{mg} / \mathrm{kg}$ body weight $(\mathrm{BW})\left(1 / 4 \mathrm{LD}_{50}\right)$, $0.625 \mathrm{mg} / \mathrm{kg} \mathrm{BW}\left(1 / 8 \mathrm{LD}_{50}\right)$, and $0.3125 \mathrm{mg} / \mathrm{kg} \mathrm{BW}\left(1 / 16 \mathrm{LD}_{50}\right)$. Mothers were exposed to carbofuran during lactation on Days 1-9. On Day 10, infant mice were sacrificed in order to determine the number of neuron cells expressing protein kinase B (Akt) and the mammalian target of rapamycin complex 1 (mTORC1) as autophagy pathway using immunohistochemistry, apoptosis using the Tunel Assay, and necrosis using haematoxylin and eosin staining. The results of Akt, mTORC1, apoptosis, and cell necrosis were analyzed by analysis of variance (ANOVA) and Duncan tests. The results of the study showed that exposing the mothers to carbofuran during lactation caused an increase in necrosis and apoptosis of neuronal cells but did not cause autophagy in neuron cells via the Akt/mTOR pathway of infant mice. The increase in apoptotic neurons opens up opportunities for the prevention and handling of the effects of reactive oxygen species activities due to carbofuran exposure during lactation periods.
\end{abstract}

Neuron cell death, Akt, mTORC1

Carbamate insecticides are widely used throughout the world due to their low toxicity and shorter half-life which causes carbamates to be widely used in place of organophosphates. Research in Blora-Central Java, Indonesia found that carbofuran residues in beef exceeded the maximum residual limit (MRL) set by the Food and Agriculture Organization (FAO), which was $169.17 \mathrm{ppb} / 0.17 \mathrm{mg} / \mathrm{kg}$ body weight (BW) (FAO standard of $50 \mathrm{ppb} / 0.05 \mathrm{mg} / \mathrm{kg}$ ) (Indraningsih 2008). Oral administration of carbofuran has been proven to stimulate reactive oxygen species (ROS) in mice brains (Kamboj et al. 2008). Intraperitoneal administration of sub-acute carbofuran has been confirmed to increase brain oxidative stress as the dose increases. An increased uncontrolled ROS will in turn lead to injury and neuron death (Gupta et al. 2007).

Carbofuran can increase embryonal neuronal necrosis and apoptosis, but no apoptosis of neurons was found in the offspring of carbofuran exposed mothers within four days of lactation (Luqman et al. 2018; Luqman et al. 2019). In the brain development stage during the embryonal period, cerebral neurons develop early and undergo a developmental peak in mid-pregnancy. Cerebellar neurons develop from mid-pregnancy until a few days after the infant is born and undergo a developmental peak at the end of the lactation period (Qiao et al. 2002). The duration and period of the effect of carbofuran on the brain development (in the foetus and offspring) provide varying results. The type of brain cell death during development due to carbofuran exposure (necrosis and apoptosis) is affected by the ROS activity (Luqman et al. 2018; Luqman et al. 2019).

Address for correspondence:

Epy Muhammad Luqman

Post Graduate School, Department of Veterinary Anatomy

Faculty of Veterinary Medicine, Universitas Airlangga

Phone : +62315041566

60286 Surabaya, Indonesia 
Oxidative stress triggers all types of cell death such as autophagy, apoptosis, and necrosis. Oxidative stress can stimulate death initiators, effector molecules and signalling pathways to determine the route of death. Autophagy is a cytoprotective process associated with apoptosis and necrosis to stimulate the pro-survival or pro-death functions. The mammalian target of rapamycin (mTOR) is a cascade signal contributing to various processes such as cell proliferation, growth, and nutrient uptake. The mammalian target of rapamycin complex 1 (mTORC1) is the hub of a major pathway for cell growth. By phosphorylating several targets, mTORC1 promotes anabolism, including mRNA translation, synthesis of lipids, purines, and pyrimidines, while inhibiting autophagy (Ben-Sahra and Manning 2017). The Akt-mTOR signalling pathway is very important in the development of cerebral neocortical nerves that play an important role in cognitive, emotional, language, and behavioral abilities (Wang et al. 2017). Protein kinase B (Akt) is known to inhibit the death of apoptotic neuron cells, and the mechanical target rapamycin (mTOR) is the downstream effect of Akt to control protein synthesis. Protein kinase B and mTOR multiple barriers reduce the acute cell death and improve the long-term cognitive deficiency after cortex effects in mice (Liu et al. 2014). Akt-mTOR inhibition reduces the necrotic cell death in the cornu amonis 3 and 1 (CA3 and CA1) regions of the hippocampus and improves the cortical function in mice (Park et al. 2012).

The understanding of the cell death mechanism and barriers to autophagic brain cell death (Akt/mTOR), apoptosis, and necrosis due to carbofuran exposure in mice during the lactation period is necessary as the basis for handling and preventing carbofuran exposure during the lactation period. The understanding of the mechanism will help determine the most sensitive period and the targeted brain cells in order to prevent exposure and thus avoid the reduction in reflexes and motoric skills in infants.

This study aimed to determine the mechanism of neuron death by autophagy, apoptosis and necrosis in infant mice (Mus musculus) from their carbofuran exposed mothers during the lactation period.

\section{Materials and Methods}

\section{Experimental animals}

This study used 20 ten-week-old female mice coming from 20 breeding mice (Mus musculus), with body weights between 25-35 grams, and 20 twelve-week-old male mice obtained from Veterinaria Farma Surabaya. The mice were adapted to the environment for 7 days and on Day 8, they were injected with pregnant mare serum gonadotropin (PMSG) (Folligon ${ }^{\mathrm{TM}}$, Intervet, Boxmeer, the Netherlands), with a dose of 5 IU/mouse. On Day 10, they were injected with human chorionic gonadotropin (hCG) (Chorulon ${ }^{\mathrm{TM}}$, Intervet, Canada) with a dose of $5 \mathrm{IU} /$ mouse and then mated with male mice (1:1). The mice were then kept in cages and fed ad libitum. On Day 11, pregnancy examination was conducted and when a vaginal plug was seen, it was declared as Day 0 of pregnancy. The pregnant mice were then grouped by 5 mice in each cage to give birth. Mothers were exposed by gavage to carbofuran/2,3-Dihydro-2,2-dimethyl-7-benzofuranol N-methylcarbamate 98\% (Aldrich Chemistry, USA, 426008-5G) at fraction doses of $1.25 \mathrm{mg} / \mathrm{kg}$ body weight $(\mathrm{BW})\left(1 / 4 \mathrm{LD}_{50}\right)$, $0.625 \mathrm{mg} / \mathrm{kg} \mathrm{BW}\left(1 / 8 \mathrm{LD}_{50}\right)$ and $0.3125 \mathrm{mg} / \mathrm{kg} \mathrm{BW}\left(1 / 16 \mathrm{LD}_{50}\right)$ from Day 1 to Day 9 of the lactation period. At the age of 10 days, the infant mice were sacrificed to collect their cerebellum, and histopathological preparations were made. One cerebellum of infant mice was used from the infant groups (litter) of a mother who exposed to carbofuran ( 5 infants per group).

Microscopic examination was carried out by calculating the expression of Akt and mTORC1 using immunohistochemistry. The brain tissue of 10-day-old mice was fixed in buffer $10 \%$ formalin and paraffin, $5 \mu \mathrm{m}$ sections were prepared and placed on object glass using polylysine. Object glasses were cooled down and blocked with 1\% bovine serum albumin/BSA (B2064, Sigma Aldrich, Saint Louis, Missouri, USA) for an hour and washed three times in phospate buffered saline (PBS) (pH 7.4) for 5 min. Slides were labelled with primary antibodies, Akt monoclonal antibody (Santa Cruz Biotechnology, USA) and mTORC1 monoclonal antibody (Santa Cruz Biotechnology) in $1 \%$ BSA overnight at $4{ }^{\circ} \mathrm{C}$. The object glasses were labelled with a biotin secondary antibody label (DakoCytomation, Denmark) in composition 1:500 for an hour at room temperature and washed using PBS ( $\mathrm{pH}$ 7.4). The object glasses were supplemented with streptavidin horseradish peroxidase (Chemicon-AP342P), 1:500, for $40 \mathrm{~min}$ and washed with PBS (pH 7.4). The glasses were then covered with diaminobenzidine tetrahydrochloride (DAB) chromogen substrate for 20 min and washed with PBS followed by washing in distilled water for $5 \mathrm{~min}$ in three repetitions and counterstained. 
Cell apoptosis examination was conducted by Tunel assay. A total of $25 \mu \mathrm{g} / \mathrm{ml}$ of proteinase $\mathrm{K}$ were applied to object glasses for $25 \mathrm{~min}$ and the glasses were washed in distilled water. Internal peroxidase activity was blocked by incubating object glasses in $3 \% \mathrm{H}_{2} \mathrm{O}_{2}$ in absolute methanol for $5 \mathrm{~min}$. The glasses were washed in PBS and incubated for an hour at $37^{\circ} \mathrm{C}$ in digoxigenin-containing solution labelled with deoxy-UTP and terminal deoxynucleotidyl transferase. Then the glasses were washed in PBS and incubated for 30 min in a solution containing anti-digoxigenin peroxidase. The glasses were washed in PBS for 5 min, incubated in diaminobenzidine solution (3,3'-diaminobenzidine tetrahydrochloride, Sigma-Aldrich), and counterstained with methyl green. Necrotic cell examination was conducted by haematoxylin and eosin (HE) staining (Hematoxylin Staining for Millicell ${ }^{\circledR}$ - HA, Merck, Germany) of the brain cells of infant mice. Three slices of each sample were observed and examined by microscope (Olympus ${ }^{\circledR}$ CX-41, Japan)

\section{Data analysis}

The mean number of cerebellar neurons expressing Akt and mTORC1 was determined under a light microscope with a $\times 400$ magnification. The expression of Akt, mTORC1 and apoptosis were identified by the colour reactions that arose which were yellowish brown. Neurons that experienced necrosis were characterized by pyknosis and karyorrhexis. Expression data of Akt and mTORC1, apoptosis, and necrosis in the brain cells of infant mice were analyzed using analysis of variance (ANOVA) test, followed by Duncan test if the results were significantly different from the control group. The value $P<0.05$ was considered to be significant. Statistical Product and Service Solution (SPSS) version 17.0 was used for statistical calculations.

\section{Results}

The brains of infant mice from mothers exposed to carbofuran for nine days showed an increase in apoptosis and necrosis $(P<0.05)$, whereas the Akt and mTORC1 expressions did not show any significant differences (Table 1$)$.

Table 1. The expressions of Akt, mTORC1, apoptosis, and necrosis in the brain of 10-days-old mice from mothers exposed to the carbofuran insecticide.

\begin{tabular}{lcccc}
\hline \multirow{2}{*}{ Groups } & \multicolumn{3}{c}{ Mean \pm SD } \\
\cline { 2 - 5 } & Akt & mTORC1 & Apoptosis & Necrosis \\
\hline Control group & $23.61 \pm 5.25^{\mathrm{a}}$ & $13.05 \pm 6.84^{\mathrm{a}}$ & $32.56 \pm 5.58^{\mathrm{a}}$ & $23.40 \pm 4.77^{\mathrm{a}}$ \\
Carbofuran $1 / 16 \mathrm{LD}_{50}=0.3125 \mathrm{mg} / \mathrm{kg} \mathrm{BW}$ & $23.73 \pm 4.37^{\mathrm{a}}$ & $13.88 \pm 5.45^{\mathrm{a}}$ & $40.07 \pm 1.61^{\mathrm{b}}$ & $23.67 \pm 8.17^{\mathrm{a}}$ \\
Carbofuran $1 / 8 \mathrm{LD}_{50}=0.625 \mathrm{mg} / \mathrm{kg} \mathrm{BW}$ & $24.64 \pm 3.48^{\mathrm{a}}$ & $10.55 \pm 2.73^{\mathrm{a}}$ & $42.79 \pm 2.16^{\mathrm{b}}$ & $41.81 \pm 12.09^{\mathrm{b}}$ \\
Carbofuran $1 / 4 \mathrm{LD}_{50}=1.25 \mathrm{mg} / \mathrm{kg} \mathrm{BW}$ & $20.77 \pm 2.04^{\mathrm{a}}$ & $10.09 \pm 2.01^{\mathrm{a}}$ & $42.97 \pm 5.65^{\mathrm{b}}$ & $43.61 \pm 15.76^{\mathrm{b}}$ \\
\hline
\end{tabular}

Different alphabetical superscripts $\left(^{\mathrm{a}, \mathrm{b}}\right)$ in the same column represent a significant difference $(P<0.05)$.

Akt - protein kinase B; mTORC1 - mammalian target of rapamycin complex 1; LD $_{50}$ - lethal dose, 50\%; BW - body weight

The results of immunohistochemical staining showed the Akt expression as a blackcoloured cytoplasm of neurons. No significant difference was found and the group exposed to carbofuran at the dose of $1.25 \mathrm{mg} / \mathrm{kg} \mathrm{BW}$ presented a $12.03 \%$ decrease in the Akt expression (Plate IX, Fig. 1).

The results of immunohistochemical staining presented the mTORC1 expression in the black-colored cytoplasm of neurons. No significant difference was found and the group exposed to carbofuran at the dose of $1.25 \mathrm{mg} / \mathrm{kg} \mathrm{BW}$ expressed a decrease in the lowest expression of $\mathrm{mTORC} 1$ protein by $22.68 \%$ (Table 1, Plate IX, Fig. 2).

As regards the appearance of apoptotic cells, they show cytoplasm in blackish brown cells, whereas healthy cells appear in green. A significant difference was found between the treatment and control groups. The highest apoptosis was found in the treatment group exposed to carbofuran at the dose of $1.25 \mathrm{mg} / \mathrm{kg} \mathrm{BW}$, compared to the control group. The increase of apoptosis in the treatment group reached $23.06 \%$ to $31.97 \%$ (Table 1, Plate X, Fig. 3). 
Haematoxylin-eosin staining indicated neuronal necrosis. It appeared that neuron cells underwent pyknosis and karyorrhexis. In the treatment group exposed to carbofuran at the dose of $1 / 8 \mathrm{LD}_{50}=0.625 \mathrm{mg} / \mathrm{kg} \mathrm{BW}$, only necrosis was shown and it was not significantly different from the group $1 / 4 \mathrm{LD}_{50}=1.25 \mathrm{mg} / \mathrm{kg} \mathrm{BW}$. The highest increase in necrosis was found in the treatment group $1 / 4 \mathrm{LD}_{50}=1.25 \mathrm{mg} / \mathrm{kg} \mathrm{BW}$ which reached $86.36 \%$ (Table 1, Plate X, Fig. 4).

\section{Discussion}

Carbofuran can increase necrosis and apoptosis in neurons during the embryonal period. Study of the effects of duration and period of carbofuran exposure on the brain development in foetus and offspring has given varying results. The type of brain cell death during development due to the exposure to carbofuran is affected by the ROS activity (Luqman et al. 2018; Luqman et al. 2019). Necrosis and apoptosis due to ROS can be triggered by autophagy through the PI3K-Akt-mTOR signal activity. Oxidative stress can cause severe damage to DNA, RNA, protein, and trigger autophagy and apoptosis (Deng et al. 2013). The PI3K/Akt/mTOR pathway plays an important role in autophagic cell modulation (Lin et al. 2016). The mechanical target rapamycin (mTOR) is one of the main modulators of autophagy which can be regulated by various signalling pathways (Sage et al. 2016).

Furthermore, Akt is known to inhibit the death of neuronal apoptosis. The double inhibition of Akt and mTOR reduces acute cell death and increases the long-term cognitive deficits in infant mice. Inhibition of Akt/mTOR does not affect the assembly of the necrosome complex but inhibits oxidative stress and cell death. Although the activation of Akt is limited as antiapoptotic, the ongoing Akt activity can increase cell death by different mechanisms (Li et al. 2011).

In this study, the administration of carbofuran did not significantly increase the expression of Akt and mTORC1 in the brain of infant mice along with the increasing dosage given to mothers from Day 1 until Day 9 of the lactation period (Table 1). Protein kinase B and mTORC1 concentrations can change due to extracellular and intracellular stimuli. Carbofuran did not increase the expression of Akt and mTORC1 neurons although carbofuran exposure during the lactation period causes an increased ROS activity (Luqman et al. 2018). However, it did not affect the number of cerebellum neurons expressing Akt and mTORC1. It suggests that the PI3K/Akt/mTOR signalling pathway did not participate in autophagy regulation caused by carbofuran exposure. Administering carbofuran during the lactation period caused a significant increase in necrotic and apoptotic cells. This means that carbofuran exposure did not cause autophagy through the ROS activity and the ROS activity can cause the process of necrosis and apoptosis (Table 1).

Reactive oxygen species are a by-product of biological reactions from energy generation, mainly produced in mitochondria through oxidative metabolism (Zorov et al. 2014). It is estimated that ROS produced by mitochondria are around $1-2 \%$ of the total level of oxygen consumption in normal cells. ROS are very small molecules, such as superoxide anion $\left(\mathrm{O}_{2}{ }^{-}\right)$, hydroxyl radical $\left({ }^{\circ} \mathrm{OH}\right)$ and hydrogen peroxide $\left(\mathrm{H}_{2} \mathrm{O}_{2}\right)$ which are produced in cell organelles, especially in mitochondria (Zhang et al. 2009). Reactive oxygen species act as the second messenger in various signal transductions. Increased ROS could not induce autophagy by increasing the expression of Akt, mTORC1 and apoptosis simultaneously or separately due to the high reactivity and damages to proteins, lipids and DNA (Chen et al. 2008).

The interaction between autophagy and apoptosis is complex and controversial, depending on the cell type and stress (Levine and Yuan 2005). Autophagy can inhibit or delay the occurrence of apoptosis, or promote apoptosis, or induce autophagic cell 
death regardless of apoptosis (Fimia and Piacentini 2010). This study revealed that carbofuran did not induce $\mathrm{PI} 3 \mathrm{~K} / \mathrm{Akt} / \mathrm{mTORC} 1$ which is a representation of the autophagic pathway, and induced apoptosis and necrosis through the ROS activity. The non-significant expression of PI3K/Akt/mTORC1 did not reduce apoptosis and necrosis of neurons due to oxidative stress.

These results could help improve the understanding in the mechanisms of neuronal death due to oxidative stress, and the intricate relationship between $\mathrm{PI} 3 \mathrm{~K} / \mathrm{Akt} / \mathrm{mTORC} 1$ which represent the pathways of autophagy, apoptosis, and necrosis. It was necessary to modulate the types of neuronal death due to oxidative stress which may be the direction of new therapies to reduce cell apoptosis and prevent the degeneration due to carbofuran exposure.

In this study, carbofuran increased neuronal apoptosis compared to controls but did not show a significant difference at higher doses (Table 1, Fig. 2). This suggests that small doses can cause apoptosis, because only very low doses can induce moderate apoptosis, whereas higher doses lead to necrosis (Burniston et al. 2005). At low doses, carbofuran could not initiate necrosis. The increase in necrosis occurred at the dose of $1 / 8 \mathrm{LD}_{50}=$ $0.625 \mathrm{mg} / \mathrm{kg} \mathrm{BW}$ and did not show any significant difference in neurons which underwent necrosis at higher doses (Table 1, Fig. 3). At the higher doses, carbofuran did not present any significant differences in apoptosis and necrosis because the body's ability to respond to carbofuran metabolites in breast milk had reached its maximum ability. The effects of chemical compounds in the body were proportional to the receptors that bind them. As Kenakin (2014) stated, the maximum effect was obtained from an injury when all receptors were bound by the chemical materials.

The number of neurons that underwent necrosis was relatively the same as the number of cells that underwent apoptosis due to carbofuran exposure. In contrast to embryonal exposure, the number of neurons that underwent necrosis was not as high as the number of cells that underwent apoptosis due to carbofuran exposure. This was due to embryonal neurogenesis; many neurons undergo physiological apoptosis as an effort to maintain homeostasis (Widjiati and Luqman 2012). This finding implies that besides not causing any cell death by autophagy, carbofuran caused necrosis and apoptosis, which opens opportunities for cell survival. These findings indicate that ROS play an important role in the process of necrosis and apoptosis caused by carbofuran exposure. However, detailed mechanisms for the process of necrosis and apoptosis must be further investigated. Thus, two or three types of cell death can be induced simultaneously or consecutively when cells are exposed to certain stimuli. If all three types of cell death were placed on an axis according to the superiority of cell survival, autophagy and necrosis would be placed at the opposite ends, whereas apoptosis would be placed in the center (Chen et al. 2018).

The conclusions of this study showed that there was no significant increase in the expression of Akt and mTORC1, apoptotic death and necrotic cells. Carbofuran exposure in mothers during the lactation period caused an increase in neuronal death by apoptosis and necrosis and a decrease in the ability of neurons to develop, especially in the expression of Akt and mTORC1.

\section{Conflict of interest}

The authors declare that they have no conflict of interest.

\section{Acknowledgements}

The authors express sincere thanks to the Ministry of Research, Technology and Higher Education of the Republic of Indonesia for funding the research, the Director of Post Graduate School for funding, and the Dean of the Faculty of Veterinary Medicine for providing all necessary facilities for conducting the study. 


\section{References}

Ben-Sahra I, Manning BD 2017: mTORC1 signaling and the metabolic control of cell growth. Curr Opin Cell Biol 45: $72-82$

Burniston JG, Chester N, Clark WA, Tan LB, David F Goldspink DF 2005: Dose-dependent apoptotic and necrotic myocyte death induced by the $\beta$-adrenergic receptor agonist, clenbuterol. Muscle Nerve 32: 767-774

Chen Q, Kang J, Fu C 2018: The independence of and associations among apoptosis, autophagy, and necrosis. Signal Transduct Target Ther. 3: 1-11

Chen Y, McMillan-Ward E, Kong J, Israels SJ, Gibson SB 2008: Oxidative stress induces autophagic cell death independent of apoptosis in transformed and cancer cells. Cell Death Differ 15: 171-182

Deng X, Zhang F, Rui W, Long F, Wang L, Feng Z, Chen D, Ding W 2013: PM2.5-induced oxidative stress triggers autophagy in human lung epithelial A549 cells. Toxicol In Vitro 27: 1762-1770

Fimia GM, Piacentini M 2010: Regulation of autophagy in mammals and its interplay with apoptosis. Cell Mol Life Sci 67: 1581-1588

Gupta RC, Milatovic S, Dettbarn WD, Aschner M, Milatovic D 2007: Neuronal oxidativer injury and dendritic damage induced by carbofuran: protection by memantine. Toxicol Appl Pharmacol 219: 97-105

Indraningsih 2008: Effect of carbamate insecticide use on animal health and its products. Jurnal Wartazoa 18: 101-114

Kamboj SS, Kumar V, Kamboj A, Sandir R 2008: mitochondrial oxidative stress and dysfunction in rat brain induced by carbofuran exposure. Cell Mol Neurobiol 28: 961-969

Kenakin TP 2014: Chapter 3: Drug-Receptor Theory. In: Kenakin TP: A Pharmacology Primer. Fourth Edition. Academic Press, 450 p.

Levine B, Yuan J 2005: Autophagy in cell death: An innocent convict? J Clin Invest 115: 2679-2688

Li Z, Yang Y, Ming M, Liu B 2011: Mitochondrial ROS generation for regulation of autophagic pathways in cancer. Mini Review. Biochem Biophys Re. Commun 414: 5-8

Lin CJ, Chen TL, Tseng YY, Wu GJ, Hsieh MH, Lin YW, Chen RM 2016: Honokiol induces autophagic cell death in malignant glioma through reactive oxygen species mediated regulation of the p53/PI3K / Akt / mTOR Toxicol signaling pathway. Appl. Pharmacol 304: 59-69

Liu Q, Qiu J, Liang M, Golinski J, van Leyen K, Jung JE, Z You Z, Lo EH, Degterev A, Whalen MJ 2014: Akt and mTOR mediate programmed necrosis in neurons. Cell Death Dis 5: e1084

Luqman EM, Sudiana IK, Darmanto W, Achmad AB, Widjiati 2019: Mouse (Mus musculus) embryonic cerebral cortex cell death caused by carbofuran insecticide exposure. J Vet Res 63: 413-421

Luqman EM, Widjiati, Yustinasari LR 2018: Brain cells death on infant mice (Mus musculus) caused by carbofuran exposure during lactation period. Kafkas Univ Vet Fak 24: 845-852

Park J, Zhang J, Qiu J, Zhu X, Degterev A, Lo EH 2012: Combination therapy targeting Akt and mammalian target of rapamycin improves functional outcome after controlled cortical impact in mice. J Cereb Blood Flow Metab 32: 330-340

Qiao D, Seidler FJ, Padilla S, Slotkin TA 2002: Developmental neurotoxicity of chlorpyrifos: what is vulnerable period? Environ Health Perspect 110: 1097-1103

Sage VL, Cinti A, Amorim R, Mouland AJ 2016: Adapting the stress response: viral subversion of the mTOR signaling pathway. Viruses 8: 152

Wang L, Zhou K, Fu Z, Yu D, Huang H, Zang X, Mo X 2017: Brain development and Akt signaling: the crossroads of signaling pathway and neurodevelopmental diseases. J Mol Neurosci 61: 379-384

Widjiati, Luqman EM 2012: The critical period and type of cell death in the embryonal brain development caused by carbofuran exposure to detect a decreasing in the reflex and motoric function on infant mice (Mus musculus). Laporan Penelitian Riset Unggulan Perguruan Tinggi. Lembaga Penelitian dan Pengabdian Kepada Masyarakat, Surabaya

Zhang H, Kong X, Kang J, Su J, Li Y, Zhong J, Sun L 2009: Oxidative stress induces parallel autophagy and mitochondria dysfunction in human glioma u251 cells. Toxicol Sci 110: 376-388

Zorov DB, Juhaszova M, Sollot SJ 2014: Mitochondrial reactive oxygen species (ROS) and ROS-induced ROS release. Physiol Rev 94: 909-950 
Plate IX

Luqman E.M. et al.: Interaction ... pp. 195-200
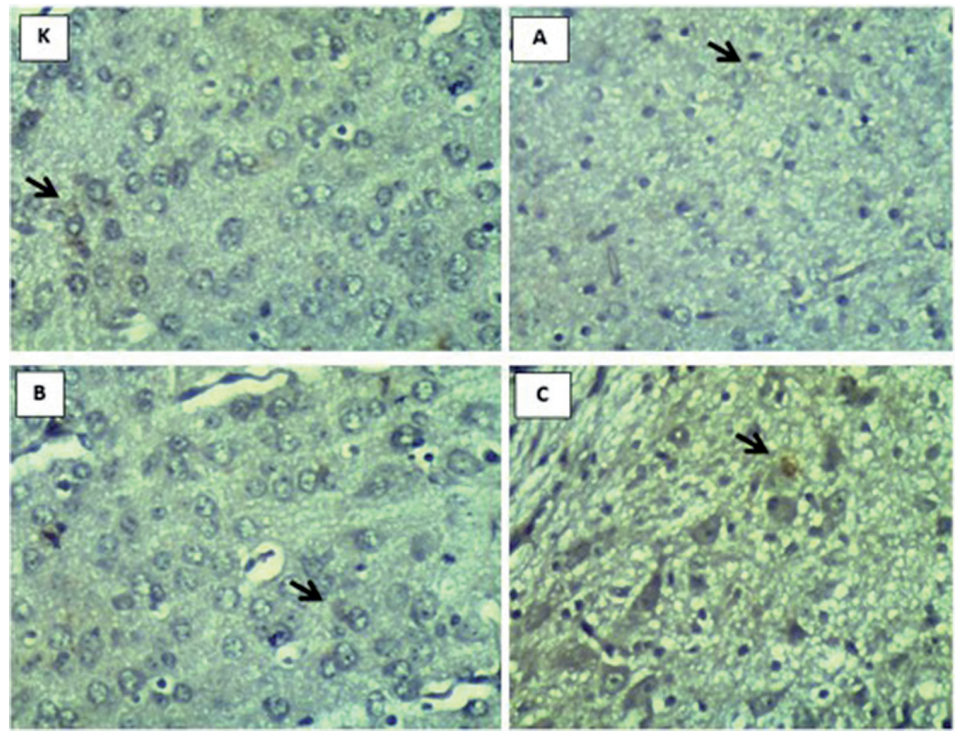

Fig. 1. The Akt expression in the brain. The arrow indicates Akt expression, which is indicated by the presence of brown chromogen (arrow). IHC, $\times 400 . \mathrm{K}$ : Control, $\mathrm{A}=1 / 16 \mathrm{LD}_{50}=0.3125 \mathrm{mg} / \mathrm{kg} \mathrm{BW}, \mathrm{B}=1 / 8 \mathrm{LD}_{50}=$ $0.625 \mathrm{mg} / \mathrm{kg} \mathrm{BW}, \mathrm{C}=1 / 4 \mathrm{LD}_{50}=1.25 \mathrm{mg} / \mathrm{kg} \mathrm{BW}$. Akt: Protein kinase B (PKB or Akt); mTORC1: Mammalian target of rapamycin complex 1; $\mathrm{LD}_{50}$ : Lethal dose, 50\%; BW: Body weight
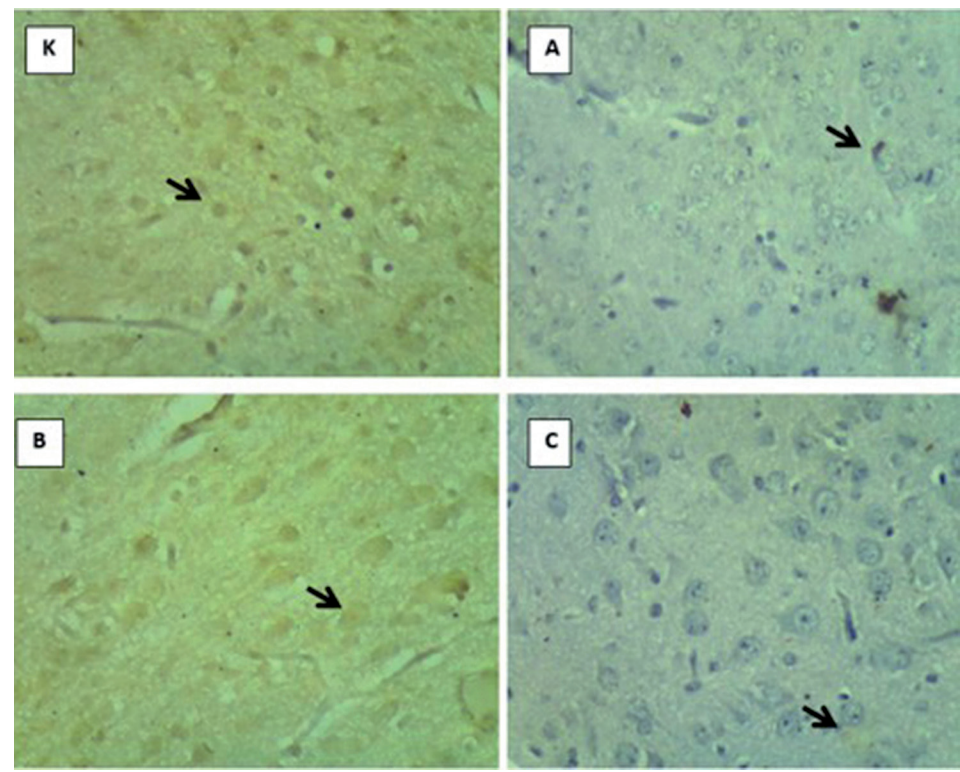

Fig. 2. The mTORC1 expression in the brain. The arrow shows the mTORC1 expression, which is indicated by the presence of brown chromogen (arrow). IHC $\times 400 . \mathrm{K}$ : Control, $\mathrm{A}=1 / 16 \mathrm{LD}_{50}=0.3125 \mathrm{mg} / \mathrm{kg} \mathrm{BW}, \mathrm{B}=$ $1 / 8 \mathrm{LD}_{50}=0.625 \mathrm{mg} / \mathrm{kg} \mathrm{BW}, \mathrm{C}=1 / 4 \mathrm{LD}_{50}=1.25 \mathrm{mg} / \mathrm{kg} \mathrm{BW}$. Akt: Protein kinase B (PKB or Akt); mTORC1: Mammalian target of rapamycin complex $1 ; \mathrm{LD}_{50}$ : Lethal dose, $50 \%$; BW: Body weight 

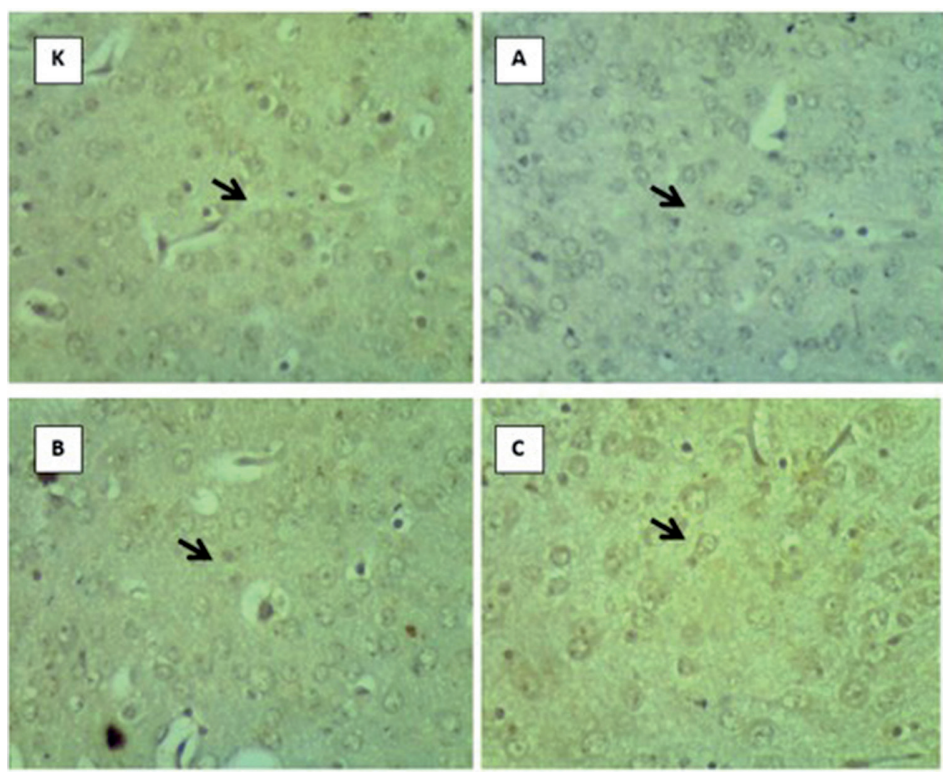

Fig. 3. Description of apoptotic expression in the brain. The arrows showed apoptotic expression, which is characterized by the presence of brown chromogen (arrow). Tunnel Assay, $\times 400 . \mathrm{K}$ : Control, $\mathrm{A}=1 / 16 \mathrm{LD}_{50}$ $=0.3125 \mathrm{mg} / \mathrm{kg} \mathrm{BW}, \mathrm{B}=1 / 8 \mathrm{LD}_{50}=0.625 \mathrm{mg} / \mathrm{kg} \mathrm{BW}, \mathrm{C}=1 / 4 \mathrm{LD}_{50}=1.25 \mathrm{mg} / \mathrm{kg} \mathrm{BW}$. Akt: Protein kinase $\mathrm{B}$ (PKB or Akt); mTORC1: Mammalian target of rapamycin complex 1; $\mathrm{LD}_{50}$ : Lethal dose, 50\%; BW: Body weight
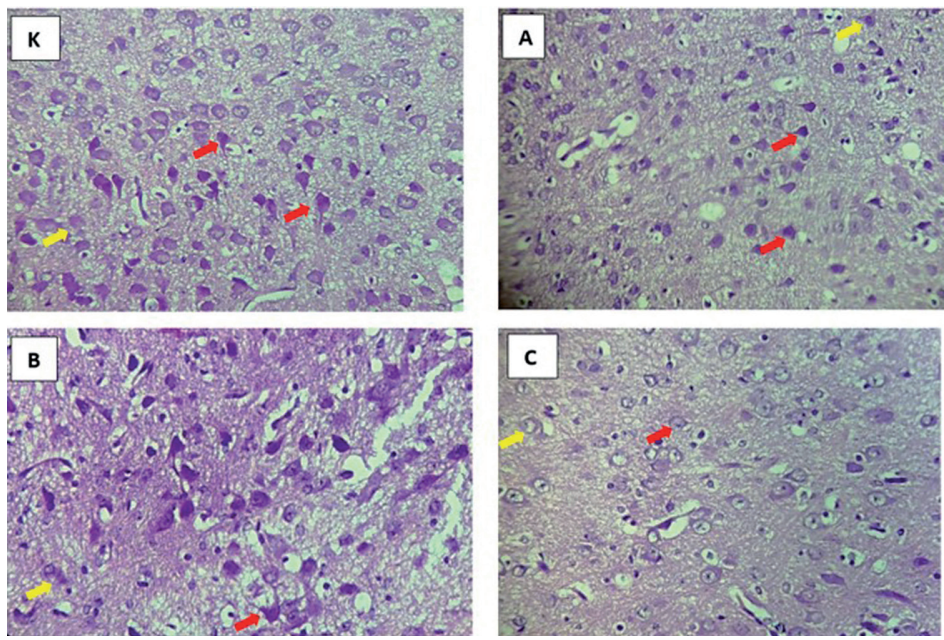

Fig. 4. Active neuron cells in the brain in each representative group. The red arrow indicates the presence of neuron cells that appeared to be active and still normal, and the yellow arrow shows the images of necrotizing neuron cells $\left(\mathrm{HE}, \times 400\right.$ magnification). $\mathrm{K}$ : Control, $\mathrm{A}=1 / 16 \mathrm{LD}_{50}=0.3125 \mathrm{mg} / \mathrm{kg} \mathrm{BW}, \mathrm{B}=1 / 8 \mathrm{LD}_{50}=$ $0.625 \mathrm{mg} / \mathrm{kg} \mathrm{BW}, \mathrm{C}=1 / 4 \mathrm{LD}_{50}=1.25 \mathrm{mg} / \mathrm{kg}$ BW. Akt: Protein kinase B (PKB or Akt); mTORC1: Mammalian target of rapamycin complex $1 ; \mathrm{LD}_{50}$ : Lethal dose, $50 \%$; $\mathrm{BW}$ : Body weight 